\title{
Evaluation of the Adoption of Improved Agricultural Practices and Factors That Affect Adoption of Tef (Eragrostis tef (Zucc) Trotter) in Ethiopia
}

\author{
Yazachew Genet ${ }^{1,}$, , Tadele Feyso ${ }^{2}$ \\ ${ }^{1}$ Ethiopian Institute of Agricultural Research, Debre Zeit Agricultural Research Centre, Debre Zeit, Ethiopia \\ ${ }^{2}$ Digital Green Foundations in Ethiopia, Addis Ababa, Ethiopia \\ Email address: \\ yazachewgenet@gmail.com (Y. Genet) \\ ${ }^{*}$ Corresponding author
}

To cite this article:

Yazachew Genet, Tadele Feyso. Evaluation of the Adoption of Improved Agricultural Practices and Factors That Affect Adoption of Tef (Eragrostis tef (Zucc) Trotter) in Ethiopia. International Journal of Agricultural Economics. Vol. 5, No. 6, 2020, pp. 293-303. doi: $10.11648 /$ j.ijae.20200506.18

Received: September 25, 2020; Accepted: October 16, 2020; Published: November 23, 2020

\begin{abstract}
The average grain yield is low (at $1.75 \mathrm{tha}^{-1}$ ). Therefore, this study aimed to analyse the adoption of improved tef practices impacting yield and factors affecting the adoption of the improved agricultural practice in four regions of Ethiopia. Household surveys and crop cut surveys were used. Four districts, 101 each in Amhara, SNNP, Tigray, and 100 farmers in Oromia regions of Ethiopia were assessed in the study. Therefore, a total of 403 respondent farmers, were used. Data were analysed using SSPS. Among the seven improved agricultural practices assessed, fertilizer application, variety selection, and use, land preparation, and herbicide application showed higher adoption among the farmers. The correlation analysis results revealed that yield is positively and significantly correlated with land preparation $(\mathrm{r}=0.492)$, row planting ( $\mathrm{r}=0.351)$ hand weeding (0.306), fertilizer application $(\mathrm{r}=0.143)$. This implies that the adoptions of these improved practices were contributing to yield increment. The result clearly indicated that the adoption of improved practices was influenced by a composite of demographic, socio-economic, and institutional factors. The partial budget analysis was employed using previous variable cost data collected in the Ada district by Debre Zeit Agricultural Research Centre. The result revealed that the highest increased income showed in Lume districts (positive net change in benefits) 37,431.2 birr ha $^{-1}$ followed by Siyadebirenawayu districts which were $31,131.73$ birr ha $^{-1}$. However, the increased income in Lemo and Lalye Maychew were minima 19513.34 birr ha $^{-1}$ and 11,469.95 birrs ha $^{-1}$ respectively. The benefit-cost ratio for Lume and Siyadebir enawayu districts were 3.9 and 3.3, respectively. However, the benefit-cost ratio for Lemo and Lalye Maychew were 1.7 and 1.9, respectively. The variables significantly affect the adoption of tef improved practices by farmers were age, education level, family size, farm size, extension service provision. To solve problems of inadequate use of improved practices, Development Agents and Agricultural experts should provide farmers with more practical pieces of training under farmers' direct participation in the demonstration centres. In order to attain food security, the nation policymakers should devise more effective farmers' training mechanisms and provide more applicable tef production mechanizations effective on the process of tef production.
\end{abstract}

Keywords: Improved Agricultural Practice, Tef, Adoption

\section{Introduction}

Tef (Eragrostis tef (Zucc.) Trotter) is indigenous cereals to Ethiopia which is its centre of both origin and diversity. Tef is number one in terms of acreage allocated to its cultivation. It is grown by about 7 million smallholder farmers on over three million hectares of land, which is equivalent to $30 \%$ of the total area allocated to cereals [6]. The wide-scale cultivation of Tef is related to its tolerance to diverse environmental constraints including both excess (waterlogging) and scarce (drought) soil moisture [12]. In addition to being nutritious, Tef grains are free of gluten [17] a causal agent for celiac disease; and hence Tef is becoming globally popular as a life-style crop [15]. It is a grain crop 
produced for human consumption almost solely in Ethiopia. It grows in most of the agro ecological zones of Ethiopia. The grain is an important crop used to make the Ethiopian staple food, injera, which is consumed at least once a day in better off households. Its straw, called chid, serves as a feed for livestock, and it is important raw material for the purpose of local house construction [13].

The Ethiopian government has developed the National Strategy document and designed to refocus national attention on Tef and work towards doubling productivity in the next five years by identifying challenges, and proposing interventions to drive transformation of the tef value chain. The adoption of improved technologies for staple crop production is an important means to increase the productivity of smallholder agriculture so as to foster economic growth and improved well-being for millions of poor households [7 $\&$ 18]. Without basic descriptive information, about who is adopting technologies and who is not, it is difficult to formulate policies for increasing agricultural productivity [8]. Technology is often used broadly to encompass physical/biological structures or objects as well as management practices. Most often, researchers are interested in the adoption of specific technology components (e.g. fertilizer) or integrated technological packages (e.g. high yielding crop variety with fertilizer). However, it may be more important to study the character or functions and impacts of these technologies [10]. Since the role of the agricultural sector and its contribution to the Ethiopian economy is very immense, the success and failure of the Ethiopian economy is highly correlated to the performance of this sector [1].

Nevertheless, the national average yield per unit area (at $1.75 \mathrm{t} \mathrm{ha}^{-1}$ ) still remains low because quite large proportions of Tef producing farmers not practicing improved agricultural practices like proper land preparation, recommended seed rate and variety, weed management, and recommended fertilizers and so on.

Digital Green (DG) is among Ethiopian Ministry of Agriculture's (MoA's) partners that have been working on improving agricultural production and productivity. DG has been working on Video-Based Agricultural extension services approach to contribute to livelihood improvement of rural communities across the country. The aim of this organization (DG) is sharing improved agricultural practices with small-scale farmers through its video-based approach for effecting interpersonal behavioural change with smallscale farmers, and this overcomes challenges posed by illiteracy to increase production and productivity by enhancing technology uptake by farmers. Therefore, to realize the benefit of this video-based extension system, crop cut and household survey was conducted with the purpose of identifying the most improved practices of the project, and to measure changes in increasing the yields of Tef, and thereby to see the production and income of smallholder farmers in some selected woredas in the major tef growing regions. The overall objective of the study was to analyse the most adopted improved agricultural practices in terms of their greater contribution for better productivity and production towards improved livelihoods of Tef producers and consumers, thereby, ensuring food security in Ethiopia.

The specific objectives of this study were

1. To evaluate different factors that affect the adoption level of improved agricultural practices (IAP) of Tef crop production between high-adopters and lowadopters producers.

2. To evaluate the effect of improved agricultural practices on yield, and identify those with greater contribution to tef productivity /production;

3. To identify barriers and triggers for adopting/not adopting recommended practices; and

4. To have strong evidence for improved practices, share to relevant small-scale farmers and recommend this approach for scaling up, and influence agricultural extension policy making in the country.

Thus, this analysis was undertaken with the aim of isolating the main factors that influence farmers' adoption behaviour and adoption of improved agricultural practices by small farmers in tef cultivation.

\section{Methodology}

\subsection{Survey Approach}

Both quantitative and qualitative methodologies (mixed approach) were used in order to assess the most adopted improved practices and different factors affecting the adoption level of improved practices on Tef crop production between high-adopters and low-adopters in the process of tef production. Accordingly, the use of mixed survey approach was ensured the generation of quantitative data [from farming households] and qualitative data [from key informants and farming households using key informant interviews (KIIs) and focus group discussion (FGDs).

\subsection{Survey Methodology}

A combination of three methodologies, which include Agronomic Assessment [using crop cut and household survey $(\mathrm{HH})$ ], Economic assessment using [crop cut and $\mathrm{HH}$ survey] and farmers perception and feedback [using KII, FGD and HH survey] were used.

\subsection{Agronomic Assessment}

In this assessment, production data were collected through direct measurement of crop yield of Tef. Tablet [CAPI] based data collection was done. In undertaking the crop cutting survey, the Living Standards Measurement Study - Integrated Surveys on Agriculture (LSMS-ISA): Ethiopia Rural Socioeconomic Survey (ERSS) crop cutting manual modified to fit Rural Socioeconomic Survey was adapted. Demarcating $1 \mathrm{M} \times 1 \mathrm{M}$ sub plot for crop cutting follow the Ethiopia Rural Socioeconomic Survey (ERSS) crop cutting manual to identify and demarcate (locate) sub plot randomly was used. A single sub-plot was selected for each household. Then, harvested crop yield rate was calculated by dividing fresh 
weight of the crop harvested in kilogram $(\mathrm{kg})$ by the area of the sub-plot in hectare.

\subsection{Types and Sources of Data}

Both qualitative and quantitative data were collected using HH survey as mentioned above and secondary data extraction from all relevant sources. Primary data was generated from beneficiary smallholder farming households in the study area or from Digital Green staff and appropriate staffs from the Ministry of Agriculture and Livestock Resources (MoALR), regional Bureau of Agriculture and Natural resource (BoANR), Woreda Agriculture and Livestock Office Experts, and Development Agent (DAs). Therefore, all relevant stakeholders, including the project beneficiary households in the sampled Woredas of the four study regions were used as source of primary data. Secondary data was generated from Digital Green database, [6] agricultural sample survey reports, price reports (producer's price) and similar researches of target area or adjacent area. Qualitative survey was collected through (FGDs) and (KIIs).

\subsection{Target Group, Sample and Sampling Procedures}

The target groups for this survey were smallholder farming households in four Woreda of 4 regional states who were treated by the project. The four districst were Lelay-machew from Tigray Region, Lemo from SNNP region, Lume from Oromia Region and Siyadebir enwayu from Amhara Region. The four regions mentioned above were identified. From each regional state a sample of district classified on the basis of their modern technology usage were selected, and from these samples of peasant associations were identified using random sampling techniques. In the first stage, one district from each region was selected and then three kebeles (is the smallest administrative unit of Ethiopia, similar to a ward, a neighbourhood or a localized and delimited group of people from each district were selected). Selection of districts was made based on the type of the crop they produce. Finally the simple random sampling techniques were employed to select ultimate sample units among smallholder farmers who were exposed to the intervention of the DG during the 2018/19 Meher (meher is the main season from May to September) season. HH level survey was administered using CAPI through CSPro application and the video based extension training participation. In the second stage of sampling, 101 farm households from Amhara, Tigiray, SNNP and 100 from Oromia districts were taken from the selected peasant associations on the basis of use of improved practices learnt from video-based extension service approach on tef production. Therefore, for this study, the client determined sample of 12 Kebeles in four Woredas and a sample of 17 households from each Kebele, making a total sample of 408 farming households. Both the sample districts used for this study were determined by DG before this survey study. Each household in a Kebele adopts at least 1 IP and thus farming households are categorized in to seven (7) adoption status Category 1 - adopting only 1 IAP, Category 2 - adopting 2
IAPs, Category 3 - adopting 3 IAPs and Category 4 adopting 4 IAPs, category 5 - adopting 5 IAPs, category- 6 adopting 6 IAPs and Category 7- adopting all IAPs.

\subsection{Methods of Data Collection and Tools}

For this qualitative crop cutting survey, a structured survey questionnaire were adapted from the Ethiopia Rural Socioeconomic Survey (ERSS) crop cutting survey tool and was modified to include only Tef crop and additional information on the type and amount of inputs applied and application of agricultural IPs, expected and actual output and amount of crop damage, if any, in addition to the usual whole plot and sub-plot size and output harvested. The data collection was carried out in person observation (experiment) and a face to face interview manner deploying trained data collectors to the respective locality. This survey tool was uploaded on tablets using CSPro software to enhance the data quality and thus the reliability of the findings from such data. Moreover to reduce the time for, and increase the probability of correct survey lot, reduces data entry and cleaning time and the errors associated with data cleaning. Before the actual implementation of the survey enumerators were given training and evaluated for the clarity and reliability of the questions.

\subsection{Focused Group Discussion}

The Focused Group Discussion (FGD) participants were chosen using stratified sampling to capture the views of the different category of farmers. FGD checklists were carefully prepared to capture all relevant information. A total of 403 farmers participated in FGD in the four districts. Each of FGD was comprised 8 to 10 individual farmers. Of 403 farmers, 161 farmers were the so called 'model farmers. The participants in the FGD were composed of elders, young people and women.

\subsection{Key Informant Interview (KII)}

The KII were conducted with DG staff, appropriate staffs from the MoALR, regional BoANR, District Agriculture and Livestock Office Experts, and DAs.

\subsection{Factors Affect the Level of Adoption of Improved Practices}

To identify the most impactful practices with greater marginal contribution to Tef productivity /production it is very important to know factors that could potentially affect the level of adoption in Tef production. Therefore, technology adoption factors were grouped into four broad categories 1), Demographic factors, 2) socio-economic factors, 3) agro ecological factors and 4) institutional factors. Therefore, under each main category some of the factors are identified based on study of the survey data in selected districts of the study area.

\subsection{Methods of Data Analysis and Presentation}

Both qualitative and quantitative methods were used in 
order to analyse collected data through questionnaires and focused group discussion. The quantitative data collected from the sample respondents were encoded in to SPSS (Statistical Package for Social Science) version 20. Simple descriptive statistics such as percentage, mean, frequency and cross tabulation were used for analysis. In order to test significance difference among variables independent sample $t$ test was used. Excel spread sheet was also used to analyse the qualitative data gathered through FGD, key informant interviews and discussion held with DAs were summarized to a manageable manner by grouping the same responses in to the same category. The major factors affecting the application of improved agricultural practices on Tef cultivation in the study area were analysed.

Partial Budget Analysis: Data on the variable cost was not collected at each woreda due to financial problem, however; at this time the Tef variable cost is almost equal in each region and woreda. Therefore, variable cost data were taken from Debre Zeit Agricultural Research Center collected from Ada District in 2018/19 for another study and used for all s districts in this study to calculate the revenue and benefit cost ratio of grain yield in the study area. However, the straw value was not calculated for this study. Therefore, partial budget analysis was employed to ensure that the Tef production is desirable and economically sound. Thus, the technique of input-output analysis indicates the cost and benefit relationship of Tef production technology as a basis for its proper evaluation and selection

\section{Results and Discussion}

\subsection{Adoption of Improved Agricultural Practice (IAP)}

Among the seven IAP assessed, fertilizer application, variety selection and use, land preparation and herbicide application showed higher adoption among the farmers (Figure 1).

\subsection{Grain Yield by Districts}

The analysis of result presented in Table 1 showed that the highest mean grain yield were obtained from Lume which is $2210.80 \mathrm{~kg} \mathrm{ha}^{-1}$ followed by Siyadebir-nawayu districts $1936.91 \mathrm{kgha}^{-1}$ of both high potential Tef growing areas during 2018/19. Result showed that there was highly significant difference $(\mathrm{P} \leq 0.01)$ for grain yield among farmers with in districts and between districts for all studied districts. This indicates that the farmers were not adopting all the improved agricultural practices being constant other factors like the agro ecology, rainfall and etc. Tef grain productivity and production partly and mainly depend on the use of improved practice applied (Table 1).

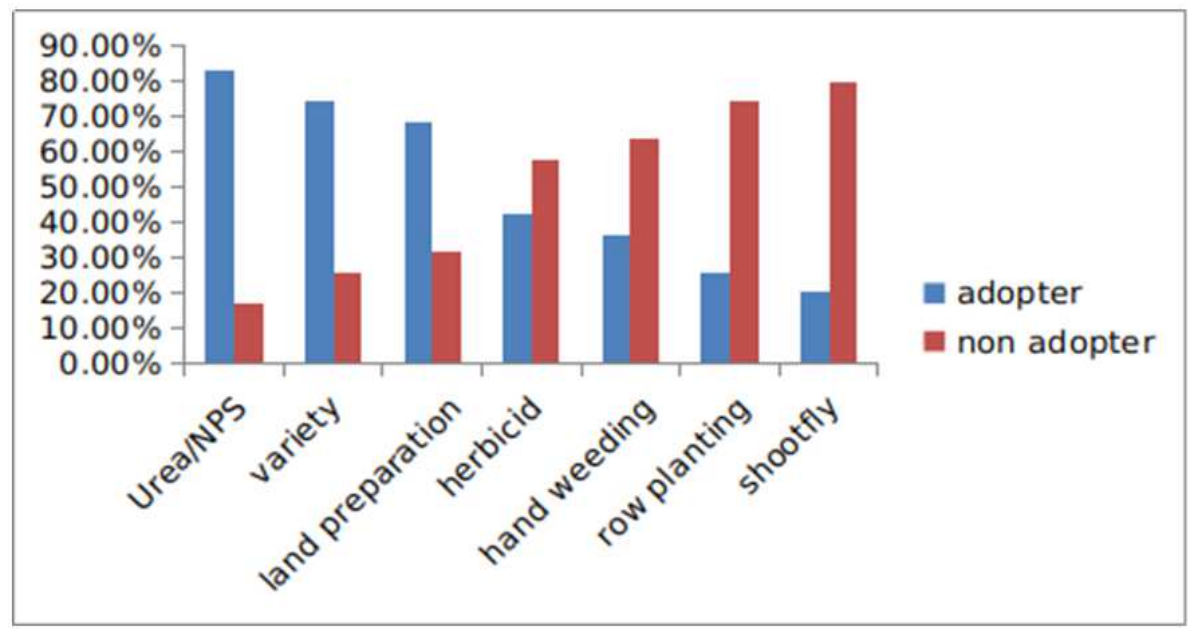

Figure 1. The adoption of Improved practices in the study.

Table 1. Table agronomic mean of grain yield obtained from survey sampled districts (Video based extension farming system).

\begin{tabular}{lllllll}
\hline District & Observation & Yield kg ha & Minimum & Maximum & t Value & Significance value \\
\hline Lelay-maichew & 101 & 1082.05 & 350.0 & 2350.0 & 28.30 \\
Lemo & 101 & 996.98 & 325.0 & 2750.00 & 24.74 \\
Lume & 100 & 2210.80 & 1075.0 & 3007.50 & 5.0001 \\
Siyadebir enawayu & 101 & 1936.91 & 722.5 & 3425.00 & 5.0001 \\
\hline
\end{tabular}

Source own survey data 2018/19.

\subsection{Correlation of the Improved Practices with Grain Yield}

The analysis result revealed that yield is positive and significant correlated with land preparation $(\mathrm{r}=0.492)$, row planting $(\mathrm{r}=0.351)$ hand weeding $(0.306)$, fertilizer application $(\mathrm{r}=0.143)$ at different level of significance with yield. This implies that the uses of these IAP were contributed for yield increment. Variety selection and application of herbicides were positive but not significant. This could be farmers did not select improved Tef varieties and use based on the recommended agro ecology, and they did not practice application of herbicides appropriately. However, further intensive training should be given for Tef producers to have good understanding and knowhow about the improved 
technologies in Tef production to increase yield.

Table 2. Pearson correlation of impactful agricultural practices with grain yield.

\begin{tabular}{|c|c|c|c|c|c|c|c|c|}
\hline & Yield & $\begin{array}{l}\text { Land } \\
\text { preparation }\end{array}$ & $\begin{array}{l}\text { Variety } \\
\text { selection }\end{array}$ & Row & Urea/NPS & herbicide & $\begin{array}{l}\text { Hand } \\
\text { weeding }\end{array}$ & $\begin{array}{l}\text { Shoot fly } \\
\text { control }\end{array}$ \\
\hline Pearson Correlation & 1 & $0.492^{* *}$ & 0.027 & $0.351^{* *}$ & $0.143^{* *}$ & 0.013 & $0.306^{* *}$ & 0.009 \\
\hline Sig. (2tailed) & & 0.000 & 0.592 & 0.000 & 0.004 & 0.799 & 0.000 & 0.799 \\
\hline Sum of Squares & 188894676.7 & 60411.0 & 3307.0 & 41270.3 & 13029.3 & 1756.8 & 34006.6 & 1756.811 \\
\hline Covariance & 469887.3 & 150.3 & 8.2 & 102.7 & 32.4 & 4.4 & 84.6 & 4.370 \\
\hline $\mathrm{N}$ & 403 & 403 & 403 & 403 & 403 & 403 & 403 & 430 \\
\hline
\end{tabular}

** Source own survey data 2018.

\subsection{Partial Budget Analysis}

The result revealed that the highest increased income showed in Lume districts (positive net change in benefits) were 37431.2 birr ha $^{-1}$ followed by Siyadebir enawayu which is 31131.73 birr ha $^{-1 .}$ However, the increase income in Lemo

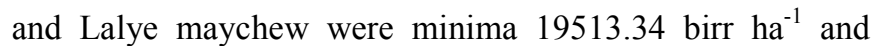
11469.95 birr, respectively ( $1 \mathrm{USD}=27.49$ birr). Therefore, farmers should adopt improved practice to increase grain yield and their income.

Table 3. Partial budget analysis for Tef production in the studied areas based on Ada district variable cost data.

\begin{tabular}{|c|c|c|c|c|c|}
\hline & & Lelay-maichew & Lemo & Lume & Siyadebir ena Wayu \\
\hline \multirow[t]{8}{*}{1} & Human Labor costs & & & & \\
\hline & Planting & 200 & 200 & 200 & 200 \\
\hline & Fertilizer application & 133.2 & 133.2 & 133.2 & 133.2 \\
\hline & Hand weeding & 1800 & 1800 & 1800 & 1800 \\
\hline & Herbicide & 600 & 600 & 600 & 600 \\
\hline & Harvesting & 800 & 800 & 800 & 800 \\
\hline & Transporting & 800 & 800 & 800 & 800 \\
\hline & Total labor cost & 5133.8 & 5133.8 & 5133.8 & 5133.8 \\
\hline \multirow[t]{5}{*}{2} & Oxen rent (birr) & & & & \\
\hline & Plowing & 2400 & 2400 & 2400 & 2400 \\
\hline & *Threshing & 2000 & 2000 & 2000 & 2000 \\
\hline & *Total oxen cost & 4400 & 4400 & 4400 & 4400 \\
\hline & Total variable Cost & 13417.2 & 13417.2 & 13417.2 & 13417.2 \\
\hline 3 & Yield (kg) & 1082.05 & 996.98 & 2210.8 & 1936.91 \\
\hline 5 & Total Revenue/benefit & 24887.15 & 22930.54 & 50848.4 & 44548.93 \\
\hline 6 & Net revenue/benefit & 11469.95 & 9513.34 & 37431.2 & 31131.73 \\
\hline 7 & Benefit cost ratio & 1.9 & 1.7 & 3.9 & 3.3 \\
\hline
\end{tabular}

NB. 1 USD $=27.49$ birr.

\subsection{Household Related Factors}

\subsubsection{The Effect of Household Size on Adoption Rate of Tef Improved Practice}

Land preparation: According to the data acquired from FGD most of the respondents suggested that the household size of the respondents significantly affects the respondents' adoptability to improved technologies. Since tef land preparation in the current situation is labour intensive method of production.

Households with large family size were able to provide more number of labour assistance from the family members. From the result showed of farmers with large family size $(>10)$ were $86.7 \%$ high adopters for recommended land preparation. Farmers with 1-3 family size were the least adopters with $61.4 \%$. From this it can be concluded that household size had a positive effect on application of recommended land preparation. In the case of high-adopters household family size and level of adoption of land preparation is strongly and positively related
Variety selection and use: As displayed in Table 4, house hold size does not have effects on adoption of selection and use of improved tef varieties. Thus, variety selection and household size have no relationship

Row planting: As it is depicted on Table 4, in the case of high-adopters household family size and level of adoption of row planting practice is strongly and positively related. In the case of low-adopters household family size had a negative relationship with the application rate of row planting. This implies that in the current situation where there is no implanting machine, row planting needs high labour.

Application of fertilizer (the time it takes to apply): The result revealed that high adopter household size and level of adoption of application of fertilizer had a negative relationship with the application of fertilizer. It can conclude that the large household size the lesser time taken to apply fertilizer.

Hand weeding: even though they were few in number high adopters, large household size and the level of adoption of hand weeding had positive relationship. This indicates that 
hand weeding needs large family size.

Herbicide application: the result did not show a relationship between household sizes with herbicide application. It implies that herbicide application does not depend on household size. The number of lower adopter of farmers was greater than higher adopter farmers.

Shootfly control from the table below the lower adopters was greater than the higher adopters. Household size did not show a relationship with shoot fly control.

In general, from the present study, land preparation, row planting, hand weeding and application of fertilizer exhibited positive relationship with hous hold size however, the rest of IAP, did not show posive relationship. Most of Large family size is normally associated with a higher labor endowment that would enable a household to accomplish various agricultural tasks on timely bases $[11,14]$

Table 4. The effect of household size on adoption rate of improved practices. High adopter (had); low adopter (lad).

\begin{tabular}{|c|c|c|c|c|c|c|c|c|c|}
\hline \multirow{3}{*}{ IAP } & & \multicolumn{8}{|c|}{ Household size } \\
\hline & & \multicolumn{2}{|c|}{$01-03$} & \multicolumn{2}{|c|}{ 04-07 } & \multicolumn{2}{|c|}{ 08-10 } & \multicolumn{2}{|c|}{$>10$} \\
\hline & & No. & $\%$ & No. & $\%$ & No. & $\%$ & No. & $\%$ \\
\hline \multirow[t]{3}{*}{ Land preparation } & $\mathrm{Had}$ & 35 & 61.4 & 197 & 71.1 & 54 & 70.1 & 13 & 86.7 \\
\hline & $\mathrm{L}$ ad & 22 & 38.6 & 80 & 28.9 & 23 & 29.9 & 2 & 13.3 \\
\hline & Total & 57 & 100 & 277 & 100 & 77 & 100 & 15 & 100 \\
\hline \multirow[t]{3}{*}{ Variety selection } & Had & 45 & 78.9 & 180 & 70.9 & 54 & 70.1 & 13 & 86.7 \\
\hline & $\mathrm{L}$ ad & 12 & 21.1 & 74 & 29.1 & 23 & 29.9 & 2 & 13.3 \\
\hline & Total & 57 & 100 & 254 & 100 & 77 & 100 & 15 & 100 \\
\hline \multirow[t]{3}{*}{ Row planting } & Had & 11 & 19.3 & 64 & 25.2 & 25 & 32.5 & 4 & 26.7 \\
\hline & $\mathrm{L}$ ad & 46 & 80.7 & 190 & 74.8 & 52 & 67.5 & 11 & 73.3 \\
\hline & Total & 57 & 100 & 254 & 100 & 77 & 100 & 15 & 100 \\
\hline \multirow[t]{3}{*}{ Fertilizer application } & Had & 55 & 96.5 & 222 & 87.4 & 64 & 83.1 & 12 & 80 \\
\hline & $\mathrm{L}$ ad & 2 & 3.5 & 32 & 12.6 & 13 & 16.9 & 3 & 20 \\
\hline & Total & 77 & 100 & 254 & 100 & 77 & 100 & 15 & 100 \\
\hline \multirow[t]{2}{*}{ Hand weeding } & Had & 12 & 17.9 & 53 & 20.9 & 16 & 20.8 & 4 & 16 \\
\hline & Total & 67 & 100 & 254 & 100 & 77 & 100 & 29 & 100 \\
\hline \multirow[t]{3}{*}{ Herbicide application } & Had & 29 & 50.9 & 127 & 50 & 51 & 54.8 & 6 & 40 \\
\hline & Lad & 28 & 49.1 & 127 & 50 & 42 & 45.6 & 9 & 60 \\
\hline & Total & 57 & 100 & 254 & 100 & 93 & 100 & 15 & 100 \\
\hline \multirow[t]{3}{*}{ Shoot fly control } & $\mathrm{Ha}$ & 22 & 38.6 & 100 & 39.4 & 26 & 33.8 & 4 & 26.7 \\
\hline & $\mathrm{L}$ ad & 35 & 61.4 & 154 & 60.6 & 51 & 66.2 & 11 & 73.3 \\
\hline & Total & 57 & 100 & 254 & 100 & 77 & 100 & 15 & 100 \\
\hline
\end{tabular}

Source our own survey data 2018.

\subsubsection{The Effect of Age Structure on Adoption of Tef Improved Practices}

Land preparation: Table 5 depicted $29.8 \%$ of the total respondents were youth for land preparation categorized in age group ranging between 20-40 years of age. The youth higher adopter exceeds the low adopter with in the same age group by $70.8 \%$. Therefore, the majority of youth age group accepts improved practice for land preparation. Similarly the majority adult and older respondents were higher adopter accounts $64 \%$ and the lower adopters $82.2 \%$ of the total respondent respectively in each age group. This implies that even though there were differences in adopting land preparation, all age groups categorized in this study accept improved land preparation practice.

Variety selection and use: in all age groups the higher adopter exceeds the low adopter for variety selection and use. Among youth respondents $75 \%$ were high adopters. Adult farmers' accounts about $73.5 \%$ were high adopters. Similarly older groups of high adopter were $63.9 \%$. This implies that youth group are more active in variety selection and use than the other age groups.

Row planting: the result indicates that low-adopter of the respondent exceeds the high-adopters in each age group.
Even though the high-adopters were lesser than the high adopters, among all the three age group, adult age groups were better adopter for row planting. Therefore, this implies that the youth and old age group did not adopt the application of row planting, this may be due to the youth and old age groups are poor and highly vulnerable to the risks of adopting row planting technology.

Fertilizer application: the youth and adult age group the high-adopters accounts $75 \%$ and $73.5 \%$ of the total respondent in each age group respectively exceed the lowadopters. Implies youth and adults are high adopters. However old age groups the low-adopter exceeds the high adopter account by $73.4 \%$. Therefore, youth and adult age group were high adopter this may be due to they are active learner than old age group.

Hand weeding: in all three age groups the low adopters exceed the high adopters for hand weeding. Therefore, it was not adopted in all age group this may be due to the fact hand weeding demands high labour. However in herbicide application in all age groups the higher adopters were exceed the low adopter. The result shows as age increase the adoption of herbicide increases this may be due to the fact that the older age group are weak.

Shoot fly control: in all age group the low adopter exceeds 
the high adopter. Even though the high adopters were lesser than low adopters, as the age increase the adoption of shootfly increase. This indicates that, may be due to understanding difference between the youth age and the old age considers the shoot fly has yield loss.

Therefore, young and adult age group were high adopter for land preparation, variety selection and use, fertilizer application. Similar report was suggested that younger farmers being more educated on the average and having longer planning horizons has a higher disposition to change are more likely to invest in new agricultural technologies [4]

Table 5. The effect of age on adoption rate of improved practices. high adopter (had); low adopter (lad).

\begin{tabular}{|c|c|c|c|c|c|c|c|}
\hline \multirow{3}{*}{ IPA } & & \multicolumn{6}{|l|}{ Age } \\
\hline & & \multicolumn{2}{|c|}{ 20-40 (youth) } & \multicolumn{2}{|c|}{ 41-60 (adults) } & \multicolumn{2}{|c|}{ Older $(>60)$} \\
\hline & & No. & $\%$ & No. & $\%$ & No. & $\%$ \\
\hline \multirow{3}{*}{ Land preparation } & $\mathrm{Had}$ & 85 & 70.8 & 140 & 64 & 51 & 82.2 \\
\hline & Lad & 35 & 29.1 & 78 & 36 & 21 & 33.9 \\
\hline & Total & 120 & 100 & 218 & 100 & 62 & 100 \\
\hline \multirow{3}{*}{ Variety Selection } & Had & 90 & 75 & 155 & 73.5 & 46 & 63.9 \\
\hline & Lad & 30 & 25 & 56 & 26.5 & 26 & 36.1 \\
\hline & Total & 120 & 100 & 211 & 100 & 72 & 100 \\
\hline \multirow{3}{*}{ Row planting } & Had & 24 & 20 & 57 & 27 & 15 & 20.8 \\
\hline & $\mathrm{Lad}$ & 96 & 80 & 154 & 73 & 57 & 79.2 \\
\hline & Total & 120 & 100 & 211 & 100 & 72 & 100 \\
\hline \multirow{3}{*}{ Fertilizer application } & Had & 105 & 87.5 & 182 & 86.3 & 66 & 26.6 \\
\hline & Lad & 15 & 12.5 & 29 & 13.7 & 182 & 73.4 \\
\hline & Total & 120 & 100 & 211 & 100 & 248 & 100 \\
\hline \multirow{3}{*}{ Hand weeding } & Had & 26 & 21.7 & 38 & 18 & 18 & 25 \\
\hline & Lad & 94 & 78.3 & 173 & 82 & 54 & 75 \\
\hline & Total & 120 & 100 & 211 & 100 & 72 & 100 \\
\hline \multirow{3}{*}{ Herbicide application } & $\mathrm{Had}$ & 68 & 56.7 & 211 & 70.1 & 72 & 75.8 \\
\hline & Lad & 52 & 43.3 & 90 & 29.9 & 23 & 24.2 \\
\hline & Total & 120 & 100 & 301 & 100 & 95 & 100 \\
\hline \multirow{3}{*}{ Shoot fly control } & $\mathrm{Had}$ & 40 & 33.3 & 79 & 37.4 & 33 & 45.8 \\
\hline & Lad & 80 & 66.7 & 132 & 62.6 & 39 & 54.2 \\
\hline & Total & 120 & 100 & 211 & 100 & 72 & 100 \\
\hline
\end{tabular}

Source our own survey data 2018.

\subsubsection{The Effect of Education on the Adoption Level of Improved Tef Practices}

Land preparation: A total of 403 sample respondents were categorized under the educational level of illiterate Among these 30 sample respondents educational grade were from grade 9-10 and they were high adopters with $93.3 \%$ of adoption rate; this implies that the level of adoption of land preparation is highly affected by the level of education, farmers with low educational attainment had low application level of new farming methods. As the local farmers' educational attainment level increases farmers' willingness to adopt land preparation practices at the same time increases.

Variety selection and use: farmers with low educational attainment had low variety selection and use adoption. From the result as the local farmers' educational attainment level increases, farmers' willingness to adopt improved variety at the same time increases.

Row planting: the result presented in Table 5, similar to variety selection and use as farmers' education level increase the row planting practice increases this is the fact the farmers' willingness and understanding of the use of improved practice increases.
Fertilizer application: all most in all education level the respondent farmers are high adopter. Therefore, the result indicates that education level did not affect the fertilizer application this may be all educational level of farmers understand the use of fertilizer.

Hand weeding: from the result displayed in Table 5 there was no constant education level of effect of on hand weeding and similarly for herbicide application. This implies that weed management practice is not adopted in all educational level of the respondent.

Shoot fly control: as the education level increased adoption of shoot fly control decreased though at grade 11-12 increased (due to small respondent number). Therefore, this implies that the higher the education level they consider the loss yield due to shoot fly is minimal.

Overall, education and application level of improved farming activities were positively related. Educational status of a farmer may directly affect adoption and application of new agricultural technologies. Evidence from various sources indicates a positive relationship between the educational levels of the household head and improved agricultural technology adoption $[4,3,5,14]$. 
Table 6. The effect of education on adoption rate of improved practices. High adopter (had); low adopter (lad).

\begin{tabular}{|c|c|c|c|c|c|c|c|c|c|c|c|c|c|}
\hline \multirow{3}{*}{ IPA } & & \multicolumn{12}{|c|}{ Education } \\
\hline & & \multicolumn{2}{|c|}{$\begin{array}{l}\text { Can't read and } \\
\text { write }\end{array}$} & \multicolumn{2}{|c|}{ Non normal } & \multicolumn{2}{|c|}{ Primary $1^{\text {st }}(1-4)$} & \multicolumn{2}{|c|}{$\begin{array}{l}\text { Primary } 2^{\text {nd }}(5- \\
8)\end{array}$} & \multicolumn{2}{|c|}{ Grade 9-10 } & \multicolumn{2}{|c|}{$\begin{array}{l}\text { Preparatory (11- } \\
\text { 12) }\end{array}$} \\
\hline & & No. & $\%$ & No. & $\%$ & No. & $\%$ & No. & $\%$ & No. & $\%$ & No. & $\%$ \\
\hline \multirow{3}{*}{$\begin{array}{l}\text { Land } \\
\text { preparation }\end{array}$} & $\mathrm{Had}$ & 117 & 68 & 31 & 58.9 & 47 & 72.3 & 60 & 75 & 28 & 93.3 & 2 & 66.7 \\
\hline & $\mathrm{Lad}$ & 55 & 32 & 22 & 41.1 & 18 & 27.7 & 20 & 25 & 2 & 6.7 & 1 & 33.3 \\
\hline & Total & 172 & & 53 & 100 & 65 & 100 & 80 & 100 & 30 & 100 & 3 & 100 \\
\hline \multirow{3}{*}{ Variety selection } & $\mathrm{Had}$ & 122 & 70.9 & 35 & 41.2 & 51 & 78.5 & 56 & 70 & 25 & 83.3 & 2 & 66.7 \\
\hline & $\mathrm{Lad}$ & 50 & 29.1 & 50 & 58.8 & 14 & 21.5 & 24 & 30 & 5 & 16.7 & 1 & 33.3 \\
\hline & Total & 172 & 100 & 85 & 100 & 65 & 100 & 80 & 100 & 30 & 100 & 3 & 100 \\
\hline \multirow{3}{*}{ Row planting } & $\mathrm{Had}$ & 32 & 18.6 & 5 & 9.4 & 21 & 32.3 & 27 & 33.8 & 18 & 60 & 0 & 0 \\
\hline & Lad & 140 & 81.4 & 48 & 90.6 & 44 & 67.7 & 53 & 66.2 & 12 & 40 & 3 & 100 \\
\hline & Total & 172 & 100 & 53 & 100 & 65 & 100 & 80 & 100 & 30 & 100 & 3 & 100 \\
\hline \multirow{3}{*}{$\begin{array}{l}\text { Fertilizer } \\
\text { application }\end{array}$} & $\mathrm{Had}$ & 146 & 84.9 & 41 & 77.4 & 52 & 80 & 66 & 82.5 & 27 & 90 & 3 & 100 \\
\hline & $\mathrm{Lad}$ & 26 & 15.1 & 12 & 22.6 & 13 & 20 & 14 & 17.5 & 3 & 10 & 0 & 0 \\
\hline & Toatl & 172 & 100 & 53 & 100 & 65 & 100 & 80 & 100 & 30 & 100 & 3 & 100 \\
\hline \multirow{3}{*}{ Hand weeding } & $\mathrm{Had}$ & 34 & 19.8 & 11 & 20.8 & 16 & 24.6 & 10 & 12.5 & 11 & 36.7 & 0 & 0 \\
\hline & Lad & 138 & 80.2 & 42 & 79.2 & 49 & 75.4 & 70 & 87.5 & 19 & 63.3 & 3 & 100 \\
\hline & Total & 172 & 100 & 53 & 100 & 65 & & 80 & & 30 & & & \\
\hline \multirow{3}{*}{$\begin{array}{l}\text { Herbicide } \\
\text { application }\end{array}$} & $\mathrm{Had}$ & 68 & 39.6 & 21 & 39.6 & 31 & 47.7 & 37 & 46.25 & 11 & 36.7 & 3 & 100 \\
\hline & $\mathrm{Lad}$ & 104 & 60.5 & 32 & 60.4 & 34 & 52.3 & 43 & 53.4 & 19 & 63.3 & 0 & 0 \\
\hline & Total & 172 & 100 & 53 & 100 & 65 & 100 & 80 & 100 & 30 & 100 & 3 & 100 \\
\hline \multirow{3}{*}{$\begin{array}{l}\text { Shoot fly } \\
\text { control }\end{array}$} & $\mathrm{Had}$ & 66 & 62.3 & 24 & 45.3 & 27 & 41.5 & 21 & 35.6 & 12 & 40 & 2 & 66.7 \\
\hline & Lad & 106 & 61.6 & 29 & 54.7 & 38 & 58.5 & 59 & 73.4 & 18 & 60 & 1 & 33.3 \\
\hline & Total & 172 & 100 & 53 & 100 & 65 & 100 & 80 & 100 & 30 & 100 & 3 & 100 \\
\hline
\end{tabular}

Source our own survey data 2018.

\subsubsection{The Effect of Farm Size on the Adoption of Improved Practices}

Land preparation: The result displayed in Table 6 revealed that the smaller the farm size is the high adopters by the respondent. Among the respondents the farm size $<1$ were high adopters' accounts $72.5 \%$. This indicates that smaller the farm size the better adoption for land preparation this may be due to tef land preparation needs high labour cost and take more time.

Variety selection and use: Respondents with farm size categorized $<1$ and 1.1- 2 hectare were high adopters; however, respondent farmers with $>3$ hectare farm size are low adopters. This is may be the fact that large farm size needs more seed and cost more seed price to use improved varieties.

Row planting: showed that the low adopters exceed the high adopters in all farm size categories. Even though the high adopters were lesser than the high adopter the smaller the farm size was the better adopter in the row planting practice. This implies that under current situation where there is no appropriate row planter, the row planting practice is time consuming and difficult to apply in large farm size.

Application of Fertilizer: the result illustrated in Table 6 respondents with the smaller farm size was the higher adopter of application of fertilizer. This is due to the fact that large farm size requires more fertilizer and costs more.

Hand weeding: respondent farmers with farm grouped under farm size $>3$ hectare were the higher adopter this is may be due to the farmers with large farm size have more household size/labour.

Herbicide application: the result exhibited as the farm size increased the application of herbicide increased this is may be due to tef weeding is time consuming and labour demanding.

Shoot fly control: as opposed to herbicide application the smaller the farm size the higher adopter the shoot fly control this may be due to farmers with small farmer size fear the yield loss by shoot fly.

Similar to the present finding a household with large family size are more likely to adopt improved agricultural technologies was reported $[2,11,14]$.

Table 7. The effect of farm size on adoption rate of improved practices. High adopter (had); low adopter (lad).

\begin{tabular}{|c|c|c|c|c|c|c|c|}
\hline \multirow{2}{*}{ IPA } & & \multicolumn{6}{|c|}{ Farm size } \\
\hline & & \multicolumn{2}{|c|}{$<1$ hectare } & \multicolumn{2}{|c|}{ 1.1-2 hectare } & \multicolumn{2}{|c|}{ 2.1->3 hectare } \\
\hline \multirow{3}{*}{ Land preparation } & Had & 100 & 72.5 & 13 & 43.3 & 5 & 41.7 \\
\hline & Lad & 38 & 27.5 & 17 & 56.7 & 7 & 58.3 \\
\hline & Total & 138 & 100 & 30 & 100 & 12 & 10 \\
\hline
\end{tabular}




\begin{tabular}{|c|c|c|c|c|c|c|c|}
\hline \multirow{3}{*}{ IPA } & \multirow[b]{3}{*}{$\mathrm{Had}$} & \multicolumn{6}{|c|}{ Farm size } \\
\hline & & \multicolumn{2}{|c|}{$<1$ hectare } & \multicolumn{2}{|c|}{ 1.1-2 hectare } & \multicolumn{2}{|c|}{ 2.1->3 hectare } \\
\hline & & 110 & 80.3 & 24 & 80 & 5 & 41.6 \\
\hline \multirow[t]{3}{*}{ Variety Selection } & Lad & 27 & 19.7 & 6 & 20 & 7 & 58.3 \\
\hline & Total & 137 & & 30 & & 12 & \\
\hline & $\mathrm{Had}$ & 34 & 14.3 & 2 & 6.7 & 1 & 8.3 \\
\hline \multirow[t]{3}{*}{ Row planting } & $\mathrm{Lad}$ & 203 & 85.7 & 28 & 93.3 & 11 & 91.7 \\
\hline & Total & 237 & & 30 & & 12 & \\
\hline & $\mathrm{Had}$ & 118 & 86.8 & 22 & 73.3 & 10 & 71.4 \\
\hline \multirow[t]{3}{*}{ Fertilizer application } & Lad & 18 & 13.2 & 8 & 26.7 & 4 & 28.6 \\
\hline & Total & 136 & 100 & 30 & 100 & 14 & 100 \\
\hline & $\mathrm{Had}$ & 51 & 37.2 & 8 & 26.7 & 7 & 53.8 \\
\hline \multirow[t]{3}{*}{ Hand weeding } & $\mathrm{Lad}$ & 86 & 62.8 & 22 & 73.3 & 6 & 46.2 \\
\hline & Total & 137 & 100 & 30 & 100 & 13 & 100 \\
\hline & Had & 62 & 45.3 & 17 & 56.7 & 6 & 50 \\
\hline \multirow[t]{2}{*}{ Herbicide application } & Lad & 75 & 54.7 & 13 & 43.3 & 6 & 50 \\
\hline & Total & 137 & 100 & 30 & 100 & 12 & 100 \\
\hline \multicolumn{8}{|l|}{ Shoot fly } \\
\hline \multirow{3}{*}{ Shoot fly control } & Had & 32 & 23.4 & 3 & 10 & 1 & 8.3 \\
\hline & Lad & 105 & 76.6 & 27 & 90 & 11 & 91.7 \\
\hline & Total & 137 & & 30 & 100 & 12 & 100 \\
\hline
\end{tabular}

Source survey own data 2018.

\subsection{Access to Extension Service}

Extension services were very important and effective to enhance the productivity of tef grain in the study area. Based on the data gathered from DAs, they pointed out that they spent much of their working time on farmers' field. They also frequently visited the working progress of farmers on the field and provide skill training and knowledge transfer.
Beside all these farmers obtained free labour support on the application of improved practices from DAs. The result shows there were farmers who have easy extension accesses with high-adopters of improved practices. Various studies in Ethiopia reported a strong positive relationship between access to information and the adoption behaviour of farmers $[16,3,14]$.

Table 8. The effect of access to extension service on adoption rate of improved practices. High adopter (had); low adopter (lad).

\begin{tabular}{|c|c|c|c|c|c|c|c|}
\hline \multirow[b]{3}{*}{ High adopter } & & \multicolumn{6}{|c|}{ Distance to extension service } \\
\hline & & \multicolumn{2}{|c|}{ 40min } & \multicolumn{2}{|c|}{ 41-80min } & \multicolumn{2}{|c|}{$80-120 \mathrm{~min}$} \\
\hline & & No. & $\%$ & No. & $\%$ & No. & $\%$ \\
\hline \multirow{4}{*}{ Land preparation } & $\mathrm{Had}$ & 243 & 70.6 & 20 & 55.6 & 4 & 50 \\
\hline & Lad & 101 & 29.4 & 16 & 44.4 & 4 & 50 \\
\hline & Total & 344 & 100 & 36 & 100 & 8 & 100 \\
\hline & $\mathrm{Had}$ & 253 & 73.5 & 32 & 88.9 & 7 & 87.5 \\
\hline \multirow[t]{3}{*}{ Variety selection } & Lad & 91 & 26.5 & 4 & 11.1 & 1 & 12.5 \\
\hline & Total & 344 & 100 & 36 & 100 & 8 & 100 \\
\hline & $\mathrm{Had}$ & 93 & 27 & 7 & 19.4 & 0 & 0 \\
\hline \multirow[t]{3}{*}{ Row planting } & Lad & 251 & 73 & 29 & 80.6 & 8 & 100 \\
\hline & Total & 344 & 100 & 36 & 100 & 8 & 100 \\
\hline & $\mathrm{Had}$ & 286 & 83.1 & 31 & 86.1 & 7 & 87.5 \\
\hline \multirow[t]{3}{*}{ Fertilizer application } & Lad & 58 & 16.9 & 5 & 13.9 & 1 & 12.5 \\
\hline & Total & 344 & 100 & 36 & 100 & 8 & 100 \\
\hline & $\mathrm{Had}$ & 143 & 41.6 & 13 & 36.1 & 3 & 37.5 \\
\hline \multirow[t]{3}{*}{ Hand weeding } & $\mathrm{Lad}$ & 201 & 58.4 & 23 & 63.9 & 5 & 62.5 \\
\hline & Total & 344 & 100 & 36 & 100 & 8 & 100 \\
\hline & $\mathrm{Had}$ & 143 & 41.6 & 16 & 44.4 & 7 & 87.5 \\
\hline \multirow[t]{3}{*}{ Herbicide application } & Lad & 201 & 58.4 & 20 & 55.6 & 1 & 12.5 \\
\hline & Total & 344 & 100 & 36 & 100 & 8 & 100 \\
\hline & Had & 81 & 23.5 & 6 & 16.7 & 1 & 12.5 \\
\hline \multirow[t]{2}{*}{ Shoot fly control } & $\mathrm{Lad}$ & 263 & 76.5 & 30 & 83.3 & 7 & 87.5 \\
\hline & Total & 344 & 100 & 36 & 100 & 8 & 100 \\
\hline
\end{tabular}




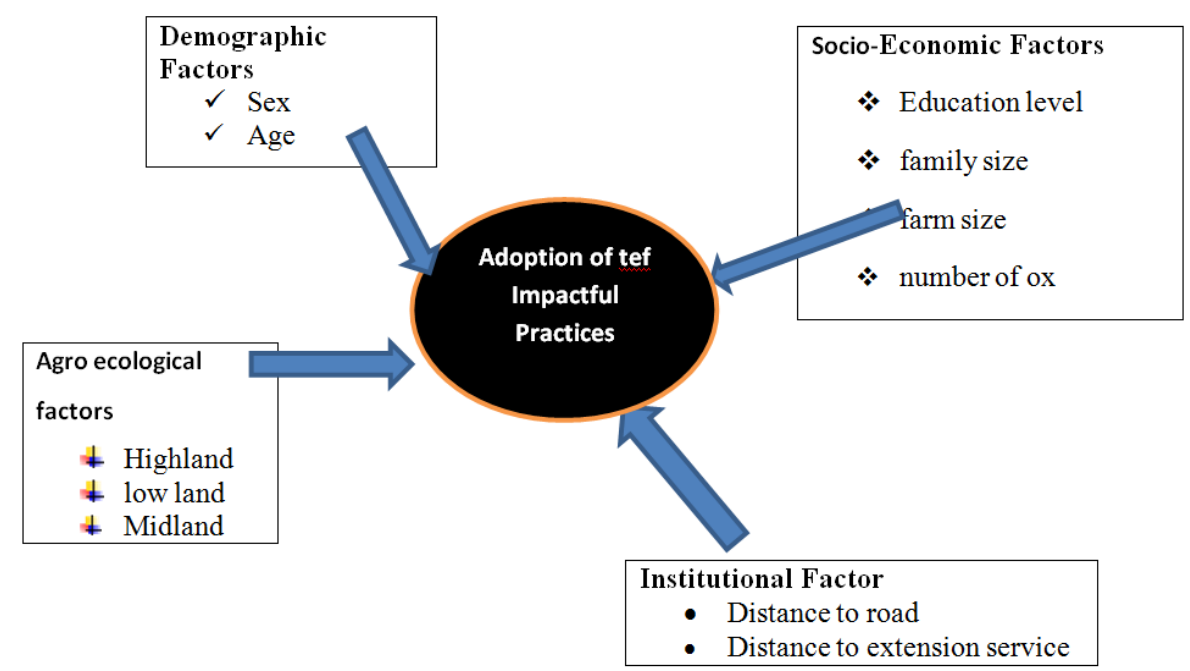

Figure 2. Conceptual frame work on the adoption of improved practice.

\subsection{Conceptual Framework on the Adoption of Improved Practices}

Previous study indicated that agricultural growth in Sub Sahara Africa (SSA) is considered to be low [9]. Ethiopia as part of SSA is struggling to improve its agricultural productivity through exposing farmers to new and modern grain production systems, and application of agricultural inputs. Tef is the major grain in Ethiopia in terms of production area and level of consumption, though its productivity is very low this resulted in high price of the product in the Tef value chain and band tef export.

From this study farmers' adoption level of modern production system- Tef impactful practices were affected by the characteristics of four major categories of factors (Figure 2) like Age, level of education, household size, farm size, number of ox they have, access to extension service, level of training provided, use of technology, agro ecology. This intern affects the level of Technology adoption.

\section{Conclusions and Recommendations}

\subsection{Conclusions}

1. Seven major tef production improved practices were identified for this survey study.

2. The result of the current study showed that majority of the farmers in the study area did not adopt all improved tef practices. Among the seven improved practices assessed, fertilizer application, variety selection and use, land preparation and herbicide application showed relatively better adoption among the farmers.

3. The most adopted improved practices impacting on yield and its correlation were identified. land preparation $(\mathrm{r}=0.492)$, row planting $(\mathrm{r}=0.351)$ hand weeding (0.306), fertilizer application $(\mathrm{r}=0.143)$. This implies that the adoptions of these improved practices were contributing to yield increment.

4. Household size had a positive effect on application of recommended land preparation, row planting, application of fertilizer and hand weeding. However, it does not have positive correlation with variety selection, shootfly control and herbicide application. In the case of high-adopters household family size and level of adoption of land preparation is strongly and positively related.

5. From age group the result showed that youth were active in variety selection and use, land preparation and fertilizer application. Likewise, Adult group were adopted row planting and fertilizer application. In contrast, the application of herbicide increases when age increases.

6. Education and application level of improved farming activities were positively related in most of the practices however, on application of herbicides and hand weeding there were no constant education effect.

7. The result indicated that smaller the farm size the better adoption for land preparation, variety selection and use, row planting. Fertilizer application and shootfly control, this may be due to tef production needs high labour cost and take more time. On the other hand, the larger the farm sizes were the high adopter in hand weeding and herbicide application.

8. In general, the result clearly indicated factors that affect the adoption of improved practices like demographic factors, socio economic factors and institutional factors.

9. Benefit cost ratio for Lume and Siyadebir enawayu districts were 3.9 and 3.3. However benefit cost ratio for Lemo and Lalye Machew were 1.7 and 1.9.

\subsection{Recommendation}

In the light of these findings, the following recommendations are forwarded in order to improve adoption of improved practice:

1. In order to improve the adoption of improved practices, Development Agents and Agricultural experts should provide farmers with more practical trainings under 
farmers' direct participation in the demonstration centres. At the same time in order to increase the support from family members, the kebeles' educational and agricultural bureaus in collaboration should train students in the school about the benefits of improved practices of tef crop; this may increase labour support that household heads obtained from their family.

2. In order to attain food security of the nation policy makers should devise more effective farmers' training mechanisms and provide more applicable tef production mechanizations effective on the process of tef production.

3. Based on the results of this study further researches can be performed in the future in order to improve tef productivity.

\section{Consent}

As per international standard or university standard, farmers written consent has been collected and preserved by the author (s).

\section{Competing Interests}

Authors have declared that no competing interests exist.

\section{References}

[1] Admassu, T., Workneh, N., \& Sisay, A. (2015). Does Farmer Field School Training Improve Technical Efficiency? Evidence from Smallholder Maize Farmers in Oromia, Ethiopia. Journal of Economics and Sustainable Development.

[2] Berhanu Gebremedhin, Fernandez-Rivera S, Mohammed Hassena, Mwangi W and Seid Ahmed. 2007. Maize and livestock: Their inter-linked roles in meeting human needs in Ethiopia (SNNPR, Oromiya and Amhara Regions) Research Report 6. ILRI (International Livestock Research Institute), Nairobi, Kenya. 103 pp.

[3] Binod Kafle. (2010). Determinants of Adoption of Improved Maize Varieties in Developing Countries: A Review. International Research Journal of Applied and Basic Sciences, Vol., 1 (1), 1-7.

[4] Chilot Yirga and Dawit Alemu. (2016). Adoption of Crop Technologies among Smallholder Farmers in Ethiopia: Implications for Research and Development. EIAR 50th Year Jubilee Anniversary Special Issue: 1-16.
[5] CSA (Central Statistics Agency), (2018). Agricultural Sample Survey: Area Planed and Production of Major Crops. Meher Season. Addis Ababa, Ethiopia.

[6] Devereux, S., \& Guenther, B. (2007). Social Protection and Support to Small Farmer Development in Ethiopia.

[7] Doss, C., Mwangi, W., Verkuijl, H., \& Groote, H. (2003). Adoption of Maize and Wheat Technologies in Eastern Africa: A Synthesis of the Findings of 22 Case Studies. Mexico: International Maize and Wheat Improvement Centre.

[8] Feder, L., R. E., Just and O., Zilberman,. (1985). Adoption of Agricultural Innovation in Developing Countries: A survey.

[9] Frank, P., \& Brent, S. (2000). Assesing the Relationships between Property Right and Technology Adoptipn in Smallholder Agriculture: A Review of Issues and Empirical Methods. Washington, D.C.: International Food Policy Research Institute.

[10] Getachew Legese, M. Jaleta, A. Langyintuo, W. Mwangi and R. La Rovere. 2010. Characterization of maize producing households in Adami Tulu - Gido Kombolcha and Adama districts in Ethiopia. Country Report, Ethiopia. Nairobi: CIMMYT.

[11] Kebebew Assefa, Yu J, K., Zeid, M., Getachew Belay, Hailu Tefera and Sorrells, M. E. (2011).

[12] Mesfin, H., Tesfaye, A., Lemlem, A., \& Eyob, M. (2004). Market access versus productivity: the case of Tef. Paper prepared for the Ethiopian Economic Association, Conference on Ethiopian Economy, Addis Ababa.

[13] Motuma Tura, Dejene Aredo, Wondwossen Tsegaye, Roberto La Rovere, Girma Tesfahun, Wilfred Mwangi and Germano Mwabu. 2010. Adoption and continued use of improved maize seeds: Case study of Central Ethiopia. African Journal of Agricultural Research Vol. 5 (17), pp. 2350-2358.

[14] Provost C and Jobson E. 2014. Move over quinoa, Ethiopia's teff poised to be next big super grain. The Guardian, January 23, 2014.

[15] Shiferaw Feleke and Tesfaye Zegeye. 2006. Adoption of improved maize varieties in Southern Ethiopia: Factors and strategy options. Food Policy, 31 (2006) 442-457.

[16] Spaenij-Dekking, L., Kooy-Winkelaar, Y., Koning, F., 2005, 'The Ethiopian cereal tef in celiac disease', New England Journal of Medicine 353 (16), 1748-1750.

[17] Setotaw Ferede. 2013. Technological Change \& Economic Viability in Tef Production. Pp 255-273. In: Kebebew Assefa, Solomon Chanyalew and Zerihun Tadele (eds). 2013. Achievements and Prospects of Tef Improvement; Proceedings of the Second International Workshop, November. 